\title{
Static Friction Tests with Various Metal Combinations and Special Lubricants
}

\author{
H. S. White and Dino Zei
}

\begin{abstract}
An inclined-plane apparatus was used in obtaining static friction data for various lubricants with different metal combinations. Special lubricants, such as chlorinated and fluorinated hydrocarbons, were compared with a reference mineral oil. The effect of additives, such as graphite, molybdenum disulfide, zinc oxide, boron nitride, and an oxidized petroleum compound, was investigated. Metal combinations involving stainless steels, carbon steel, cast iron, aluminum alloy, and chromium plate were used.

It was found that the special chlorinated and fluorinated lubricants without additives gave higher friction than the Navy symbol 2110 reference oil. A lubricant containing the oxidized petroleum compound and one containing a silicone grease gave slightly less friction than the reference oil. With a mineral lubricating grease, with dry molydenum disulfide, and with lubricants containing graphite or molybdenum disulfide, the friction was about 50 percent less than with the reference oil. The remaining lubricants gave higher friction than the 2110 reference oil.

In general, the heat-treated stainless-steel combinations gave the lowest friction, whereas the combinations involving cast iron or aluminum alloy gave relatively high friction. Friction was less with lapped and polished surfaces than with ground surfaces.
\end{abstract}

\section{Introduction}

Static friction data were obtained for making a practical comparative evaluation of the oiliness of special lubricants when used with various metal combinations. Navy symbol 2110 oil was used as a reference lubricant for comparing the friction obtained with the special lubricants. The work was done at the request of the Naval Ordnance Laboratory, which furnished most of the lubricants and the unmachined metals and specified the metal combinations to be used. The time allotted did not permit a comprehensive investigation, but it is believed that the data may be helpful to those interested in the use of these types of lubricants and metal combinations.

\section{Apparatus}

An inclined-plane apparatus was used for making the static friction tests. The coefficient of friction, $f$, is defined as $F / W$, where $F$ is the tangential force at the sliding surface, and $W$ is the force normal to the surface. As is customary with this type of apparatus, the tangent of the angle with the horizontal when a rider on the incline starts to slide is used as a measure of $f$. For a given vertically applied load, the magnitude of $W$ changes with the angle of the inclined plane, and the distribution of the load at the sliding surface varies with the angle. However, these variations are not important, as the coefficient of friction was found to be practically independent of load over a wide range.

The testing machine is shown in figure 1. An electric hot plate is mounted on transite between two journals. A handwheel acts through a 100-to-1 reduction gear to give slow tilting of the hot plate. A pointer, perpendicular to the hot plate, indicates on a calibrated scale the tangent of the angle between the surface of the hot plate and the horizontal. The heavy cylindrical weight at one corner of the transite mounting is used to load the reduction gear in one direction, thus eliminating backlash. The plate specimen is fastened to the hot plate with two screws. A loading yoke with a weight pan and weights gives the desired load on the rider specimen. Two steel bars (thicker than the plate specimen), fastened to the hot plate, have several pairs of tapped holes to allow fastening of cross bars at different positions. One of these cross bars (at the left in fig. 1) is pro-

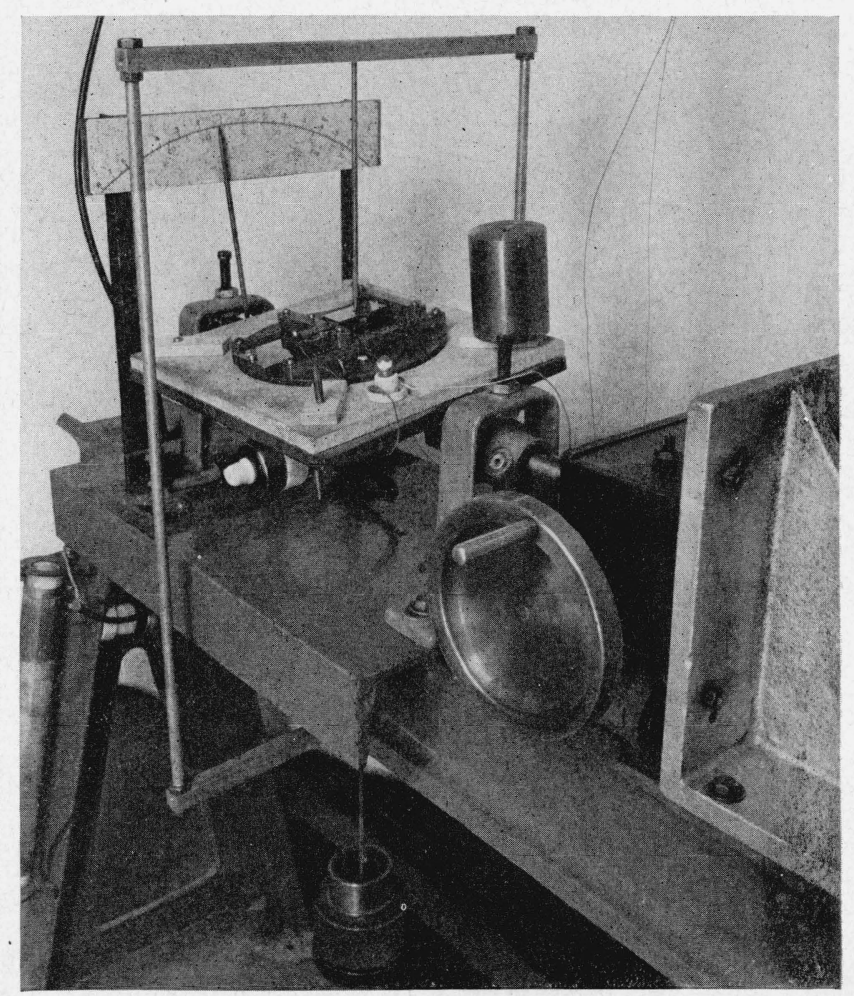

Figure 1. Static friction machine. 
vided with an electrically insulated screw and needle that are connected in series with a dry cell, lamp, and rider. Connection from the lamp to the rider is made with a No. 38 copper wire in such a way as not to influence movement of the rider. When the rider contacts the needle, the completed circuit is indicated by the signal lamp. The temperature, controlled manually, is measured by a thermocouple fastened to the plate specimen.

Typical test specimens are shown in figure 2 . The plate dimensions are $3 / 8$ in. by $2 \mathrm{in}$. by $7 \mathrm{in}$., and the rider dimensions are $\frac{1}{2}$ by 1 by 2 in. Each rider has a cone-shaped depression formed in the center of its upper surface for locating the point of the loading yoke. The central portion of the underside of each rider is undercut so as to leave a bearing surface $1 / 8$ by 1 in. at each end. The tapped holes for fastening the thermocouple to the plates and the screws for fastening the signal light wire to the riders are shown in figure 2. The rider and plate shown in the background were finished by grinding. After the plate shown in the foreground was ground, it was lapped, and the contacting surfaces of the rider were finished by lapping and polishing.

\section{Metal Combinations}

The code numbers and descriptions of the plate specimens are given in the following tabulation.

\begin{tabular}{|c|c|c|c|c|}
\hline Code No. & Material & 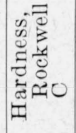 & 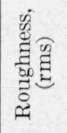 & Remarks \\
\hline $\begin{array}{l}431 \\
431-\mathrm{L} \\
440 \mathrm{C}-\mathrm{L} \\
214 \\
214-\mathrm{L} \\
2-\mathrm{L}\end{array}$ & $\begin{array}{l}431 \text { stainless steel } \\
\text { do } \\
440 \mathrm{C} \text { stainless steel } \\
214 \text { Alcoa alloy } \\
\text { cast iron }\end{array}$ & \begin{tabular}{r}
42 \\
42 \\
54 \\
- \\
\hdashline \\
-
\end{tabular} & $\begin{array}{r}\mu \text { in. } \\
9 \\
1 \\
1 \\
4 \\
3 \\
2\end{array}$ & $\begin{array}{l}\text { Dry-ground. } \\
\text { Dry-ground and lapped. } \\
\text { Do. } \\
\text { Kerosine-ground. } \\
\text { Kerosine-ground and lapped. } \\
\text { Oil-ground and lapped. }\end{array}$ \\
\hline
\end{tabular}

The code numbers and descriptions of the rider specimens are given in the following tabulation.

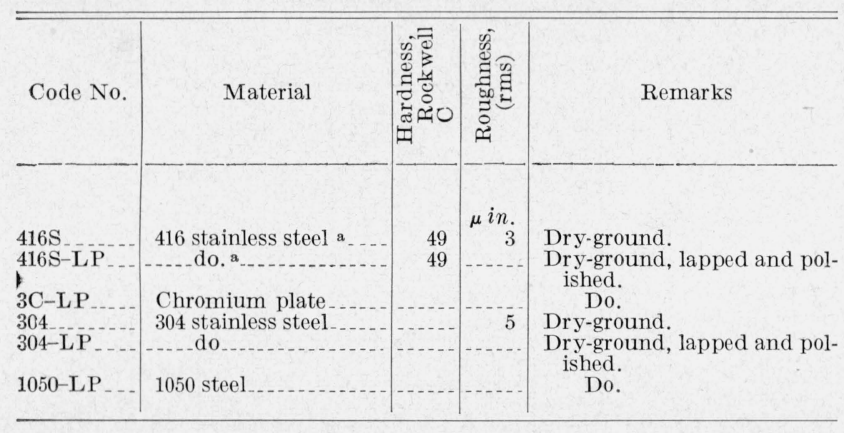

a Sulfurized for free machining.

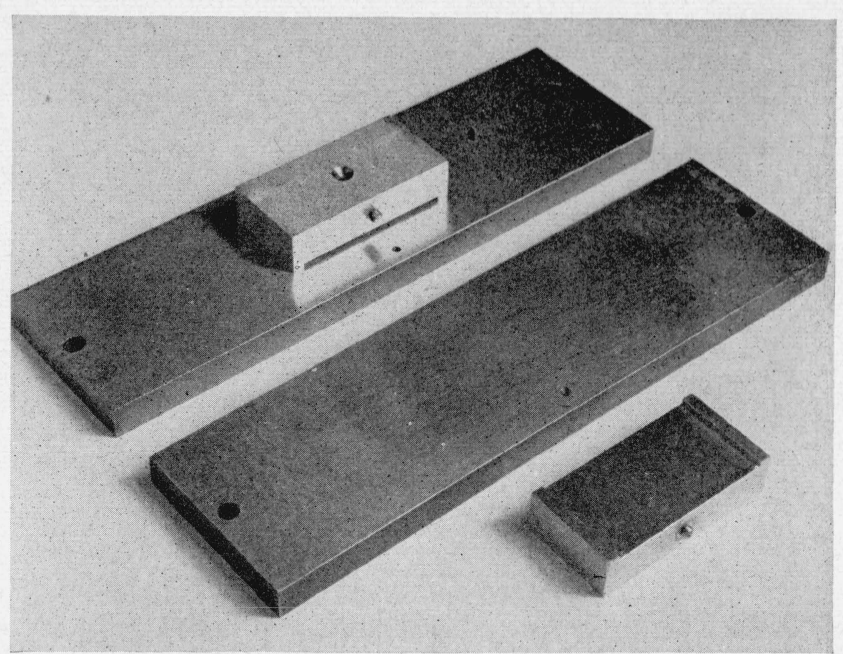

Figure 2. Static friction machine specimens.

The specimens of stainless steel 431, 440C, and 416 were hardened by heating to $1,850^{\circ} \mathrm{F}$ and quenching in oil, and tempered by heating at $500^{\circ} \mathrm{F}$ for $1 \mathrm{hr}$ and cooling in air.

The sharp edges of the $1 / 8$ by 1 -in. contact surfaces of the riders were stoned and polished to prevent any shaving effect.

The values of roughness given are in microinches (rms) as determined by an Abbot Profilometer. With the lapped cast iron $(2-\mathrm{L})$ the open pores gave erratic high readings above $2 \mu$ in., but examination with an interference microscope indicated a roughness of about $2 \mu$ in., if the pores were neglected. With the ground riders, roughness was measured on the backs of the specimens, which were ground in the same manner as the contacting surfaces. It is assumed that the lapped and polished surfaces of the riders had a roughness less than $1 \mu$ in. In the code numbers, L means lapped, and LP means lapped and polished.

A cast iron plate with grids was used to charge a similar lead-tin-alloy plate, which was then rinsed and used to lap the test specimens. This method prevented charging of the specimens with abrasives. After lapping the riders were polished on $4 / 0$ polishing paper resting on a surface plate.

The specimen combinations used in these tests are listed in the following tabulation.

\begin{tabular}{|c|c|}
\hline Rider & Plate \\
\hline $\begin{array}{l}416 \mathrm{~S} \\
304 \\
416 \mathrm{~S}-\mathrm{LP} \\
3 \mathrm{C}-\mathrm{LP} \\
304-\mathrm{LP} \\
1050-\mathrm{LP}_{-}\end{array}$ & $\begin{array}{l}431 . \\
214 . \\
431-\mathrm{L} \text { and } 440 \mathrm{C}-\mathrm{L} . \\
\text { 431-L and } 214-\mathrm{L} . \\
\text { 214-L. } \\
\text { 2-L. }\end{array}$ \\
\hline
\end{tabular}




\section{Lubricants}

The lubricants used in this investigation are listed in the following tabulation.

\begin{tabular}{|c|c|c|}
\hline $\begin{array}{l}\text { Series } \\
\text { No. }\end{array}$ & $\begin{array}{l}\text { Code } \\
\text { No. }\end{array}$ & Lubricant \\
\hline & 7 & Navy symbol 2110 oil (SAE 10 ). \\
\hline 1 & 13 & Chlorinated hydrocarbon. \\
\hline 1 & 14 & Organic phosphate ester. \\
\hline 1 & 15 & Fluorinated hydrocarbon S (medium viscesity). \\
\hline 2 & 16 & $\begin{array}{l}\text { Fluorinated hydrocarbon } \mathrm{S}+1 \% \text { commercial } \\
\text { additive, oxidized petroleum compound. }\end{array}$ \\
\hline 2 & 17 & $\begin{array}{l}\text { Fluorinated hydrocarbon } \mathrm{S}+1 \% \text { molybdenum } \\
\text { disulfide. }\end{array}$ \\
\hline 3 & 18 & Fluorinated hydrocarbon FS (light viscosity). \\
\hline 3 & 19 & Fluorinated hydrocarbon $\mathrm{S}+1 \%$ graphite. \\
\hline $\begin{array}{l}3 \\
4\end{array}$ & $\begin{array}{l}20 \\
21\end{array}$ & Perfluorokerosene. \\
\hline 4 & 22 & Silicone DC-200 (100 centistokes at $\left.25^{\circ} \mathrm{C}\right)$ \\
\hline 4 & 23 & $\begin{array}{l}\text { Fluorinated hydrocarbon } \mathrm{FS}+2 \% \text { silicone grease } \\
\text { DC }-44 \text { (medium). }\end{array}$ \\
\hline 4 & 24 & Fluorinated hydrocarbon KEL-F. \\
\hline 4 & 25 & $\begin{array}{l}\text { Fluorinated hydrocarbon } \mathrm{FS}+5 \% \text { fluorinated } \\
\text { grease (light). }\end{array}$ \\
\hline $\begin{array}{l}5 \\
5\end{array}$ & $\begin{array}{l}26 \\
27\end{array}$ & $\begin{array}{l}\text { Grease } \mathrm{G}(23.5 \% \text { sodium soap). } \\
\text { Grease } \mathrm{G}+5 \% \text { molybdenum disulfide. }\end{array}$ \\
\hline 5 & 28 & Molybdenum disulfide (dry). \\
\hline 5 & 29 & 2110 oil $+1 \%$ molybdenum disulfide. \\
\hline 5 & 30 & Fluorinated hydrocarbon F S+1\% zinc oxide. \\
\hline 6 & 31 & $\begin{array}{l}\text { Fluorinated hydrocarbon } \mathrm{S}+2 \% \text { molybdenum } \\
\text { disulfide concentrate. }\end{array}$ \\
\hline 6 & 32 & $\begin{array}{l}\text { Fluorinated hydrocarbon } \mathrm{S}+0.75 \% \text { boron nitride } \\
\text { (amorphous). }\end{array}$ \\
\hline
\end{tabular}

Lubricant 7 was selected as the reference oil for comparing the frictional characteristics of the samples, most of which were furnished by the Naval Ordnance Laboratory. The lubricants were received in groups and each group was assigned a series number.

\section{Test Procedure}

For cleaning the test specimens, five solvents were used in the following order: Stoddard solvent; carbon tetrachloride; benzene, cp; acetone, cp; ethyl alcohol, 95 percent. Absorbent cotton was used for scrubbing the specimens with the first two solvents. This was followed by rinsing with the other three and drying with clean cotton.

The liquid lubricants were applied to the plates and riders by means of small clean cotton swabs. Grease samples were applied with a finger tip and dry molybdenum disulfide by dusting.

With the plate horizontal, the rider was placed in position, contacting the insulated needle, and the load was applied. The needle was retracted 0.006 in. ( $1 / 4$ turn of the screw), and the plate was tilted slowly until the rider moved sufficiently to contact the needle and light the signal lamp. The tangent of the angle of tilt was recorded. A second reading was obtained by leveling the plate, retracting the needle another 0.006 in., and again tilting the plate until the signal lamp was lighted. This was repeated, usually until eight readings were obtained, giving a total movement of the rider of 0.048 in. This procedure and series of readings were considered as one test. Between tests the specimens were cleaned and the needle was returned to its original position so that the next lubricant could be tested on the same area of the plate specimen. Because of the variation in static friction resulting from such things as the presence of the oxide films, microscopic irregularities of the metal surfaces, and contamination from the atmosphere, tests with the reference oil (Navy symbol 2110) were made in conjunction with each series of special lubricants. For example, with series No. 1 and one needle bar position, tests were made with lubricants in the following order of Code Nos.: 7, 7, $13,7,14,7,15,7$. After all the lubricants of a series had been tested at one plate area, the needle bar was moved to another position, the rider was lapped and polished again, and the series was tested at the new plate area. In general, these comparative tests were made at three different areas of the plate specimens. With each new surface area, two or more tests were made with the 2110 oil to assure reasonable reproducibility before testing the series of lubricants. After three areas had been used on a plate specimen, it was lapped again before being used with the next series of lubricants.

\section{Test Results}

Some preliminary testing was done in order to study reproducibility and the effects of temperature and load. The effect of temperature was small and was within probable experimental error for the range of $80^{\circ}$ to $120^{\circ} \mathrm{F}$. Tests with loads of 5,10 , and 15 lb. indicated that variation in the load had no effect on the coefficient of friction, that is, the tangent of the angle when sliding occurred. This was checked later with the 2110 reference oil and special lubricants 16 and 17 , with the $416 \mathrm{~S}-\mathrm{LP}$ rider on the $431-\mathrm{L}$ plate. All the values of coefficient of friction reported herein were obtained at a nominal temperature of $100^{\circ} \mathrm{F}$ and with a $10-\mathrm{lb}$. load (40 lb/in. ${ }^{2}$ average).

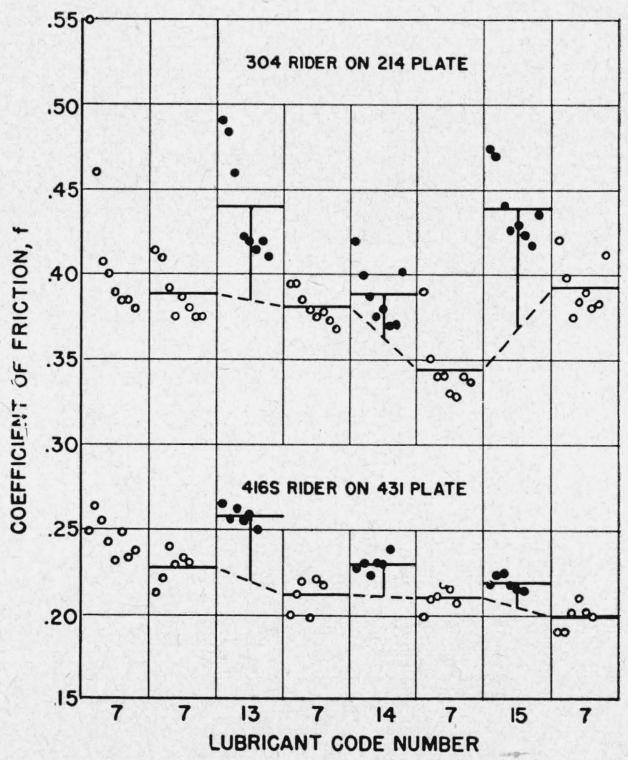

Figure 3. Representative friction data at 10-lb load and $100^{\circ}$ $F$, with ground surfaces. 


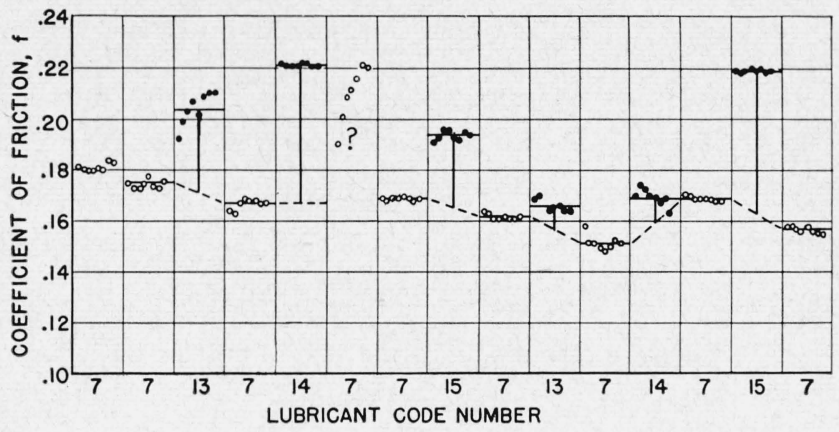

FIgURE 4. Representative friction data at 10-lb load and $100^{\circ}$ $F$, with 416S-LP rider on 431-L plate (first series of lubricants).

Some tests were made with ground surfaces on the metal specimens. Typical data for the 2110 reference oil and lubricants 13,14 , and 15 are shown in figure 3. The horizontal lines represent the averages for each group of data obtained in a test. The averages for the reference oil are connected by broken lines from which vertical lines are drawn to the averages for the special lubricants.

Due to the large spread of data on ground surfaces and the fact that lapped or lapped-and-polished surfaces are more easily reproduced and are more commonly used for machine parts involving small clearances, subsequent tests were made with lapped plates and lapped-and-polished riders. The lapping and polishing processes have already been described.

Figure 4 shows typical data for the first series of lubricants with the $416 \mathrm{~S}$ lapped-and-polished stainless-steel rider on the 431 lapped stainless steel plate. Where a test was obviously not representative it was ignored, as indicated by the question mark for one of the tests with oil 7 . Otherwise, the spread of data in figure 4 is much less than in figure 3.

Representative data for the second and fifth series of lubricants are shown in figures 5 and 6 , respectively.

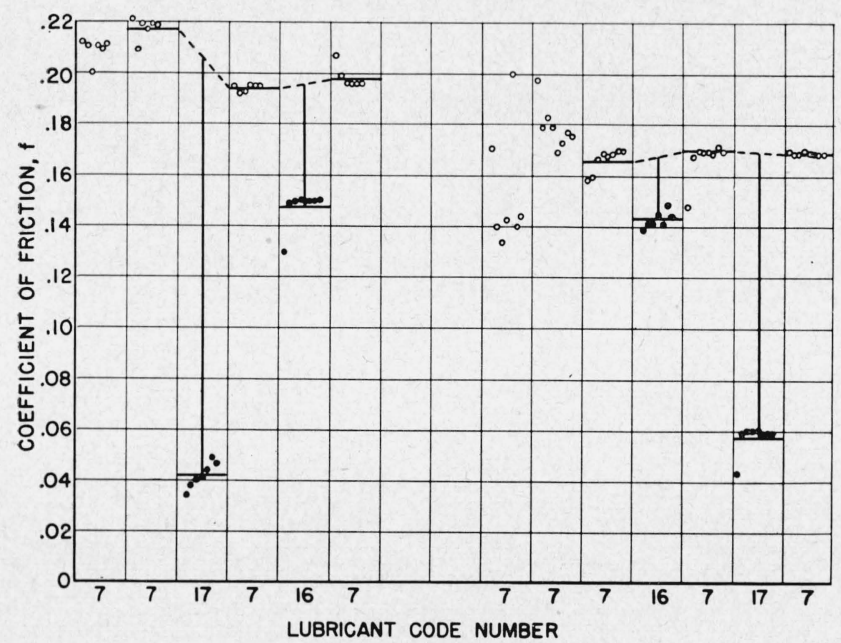

Figure 5. Representative friction data at 10-lb load and $100^{\circ}$ $F$, with $416 S-L P$ rider on $431-L$ plate, at two locations on the plate (second series of lubricants).
The data for all the lubricants with this particular metal combination are given in table 1 . These were obtained from plots similar to figures 4,5 , and 6 . The position number refers to the position of the needle bar, and hence each different position means a different location of the rider on the plate specimen. The spread of data is indicated by giving the maximum and minimum readings for each test, and the average corresponds to the horizontal mean lines as in figures 4,5 , and 6 . The percentage increase in friction corresponds to the vertical lines connecting the means to the broken lines for the 2110 reference oil. The percentage increase is indicated as negative when the friction is less than with the reference oil. The reference values of $f$ used for the 2110 oil in connection with each special lubricant test is given in the last column.

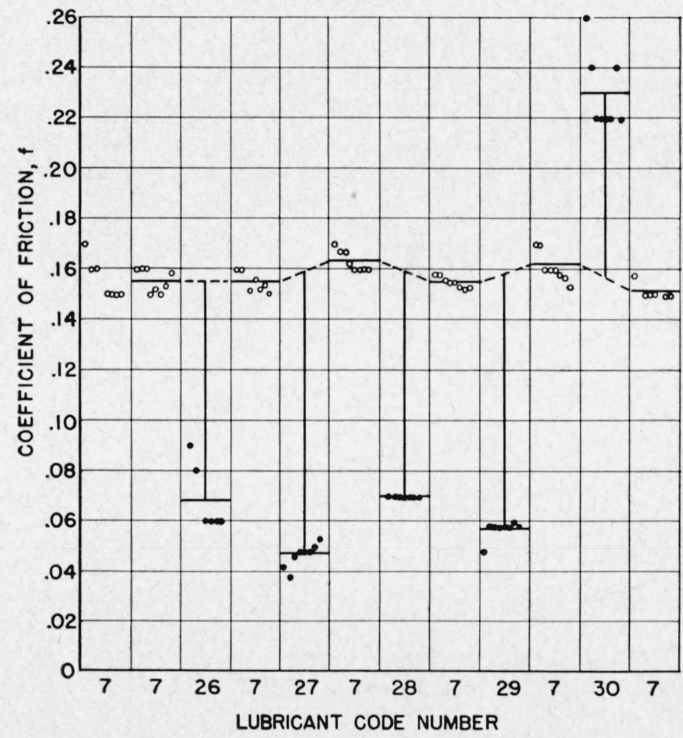

Figure 6. Representative friction data at 10-lb load and $100^{\circ}$ $F$, with 416S-LP rider on 431-L plate (fifth series of lubricants).

TABLE 1. Static friction data at 10-lb. load and $100^{\circ} \mathrm{F}$. for 416 stainless steel $(416 \mathrm{~S}-L P)$ on 431 stainless steel $(431-L)$

\begin{tabular}{|c|c|c|c|c|c|c|c|}
\hline \multirow{2}{*}{$\begin{array}{l}\text { Test } \\
\text { No. }\end{array}$} & \multirow{2}{*}{$\begin{array}{c}\text { Position } \\
\text { No. }\end{array}$} & \multirow{2}{*}{$\begin{array}{c}\text { Lubri- } \\
\text { cant } \\
\text { Code } \\
\text { No. }\end{array}$} & \multicolumn{3}{|c|}{ f (tangent) } & \multirow{2}{*}{$\begin{array}{l}\text { Percent- } \\
\text { age in- } \\
\text { crease a }\end{array}$} & \multirow{2}{*}{ f 2110} \\
\hline & & & $\begin{array}{l}\text { Maxi- } \\
\text { mum }\end{array}$ & $\begin{array}{l}\text { Mini- } \\
\text { mum }\end{array}$ & A verage & & \\
\hline 61 & 7 & 13 & 0.210 & 0.192 & 0.204 & 19 & 0.172 \\
\hline 68 & 7 & 13 & .190 & .184 & .186 & 19 & .156 \\
\hline 78 & 5 & 13 & .160 & .146 & .153 & 10 & .138 \\
\hline 63 & 7 & 14 & .222 & .221 & .221 & 32 & .167 \\
\hline 72 & 7 & 14 & .220 & .218 & .219 & 34 & .163 \\
\hline 80 & 5 & 14 & .190 & .178 & .182 & 34 & .136 \\
\hline 66 & 7 & 15 & .196 & .191 & .194 & 17 & .166 \\
\hline 70 & 7 & 15 & .174 & .164 & .169 & 6 & .160 \\
\hline 76 & 5 & 15 & .141 & .138 & .139 & -2 & .142 \\
\hline 213 & 3 & 16 & .167 & .162 & .165 & -13 & .186 \\
\hline 221 & 5 & 16 & .150 & 130 & 147 & -25 & .196 \\
\hline 226 & 7 & 16 & .149 & .139 & .143 & -15 & .168 \\
\hline 215 & 3 & 17 & .089 & .078 & .086 & -52 & .179 \\
\hline 219 & 5 & 17 & .049 & .034 & .042 & -80 & .205 \\
\hline 228 & 7 & 17 & .060 & .043 & .057 & -67 & .170 \\
\hline 353 & 3 & 18 & .219 & .194 & .203 & 18 & .172 \\
\hline
\end{tabular}

a Percentage increase in average $f$ relative to tests with 2110 oil. 
TABLE 1. Static friction data at 10-lb. load and $100^{\circ} \mathrm{F}$. for 416 stainless steel $(416 S-L P)$ on 431 stainless steel $(431-L)-$ Continued

\begin{tabular}{|c|c|c|c|c|c|c|c|}
\hline \multirow{2}{*}{$\begin{array}{l}\text { Test } \\
\text { No. }\end{array}$} & \multirow{2}{*}{$\begin{array}{l}\text { Position } \\
\text { No. }\end{array}$} & \multirow{2}{*}{$\begin{array}{c}\text { Lubri- } \\
\text { cant } \\
\text { Code } \\
\text { No. }\end{array}$} & \multicolumn{3}{|c|}{$f$ (tangent) } & \multirow{2}{*}{$\begin{array}{l}\text { Percent- } \\
\text { age in- } \\
\text { crease a }\end{array}$} & \multirow{2}{*}{ f 2110} \\
\hline & & & $\begin{array}{l}\text { Maxi- } \\
\text { mum }\end{array}$ & $\begin{array}{l}\text { Mini- } \\
\text { mum }\end{array}$ & A verage & & \\
\hline $\begin{array}{l}365 \\
371\end{array}$ & $\begin{array}{l}5 \\
7\end{array}$ & $\begin{array}{l}18 \\
18\end{array}$ & $\begin{array}{l}.171 \\
.154\end{array}$ & $\begin{array}{l}.160 \\
.137\end{array}$ & $\begin{array}{l}.164 \\
.142\end{array}$ & $\begin{array}{r}3 \\
-1\end{array}$ & $\begin{array}{l}.159 \\
.144\end{array}$ \\
\hline $\begin{array}{l}355 \\
363 \\
369\end{array}$ & $\begin{array}{l}3 \\
5 \\
7\end{array}$ & $\begin{array}{l}19 \\
19 \\
19\end{array}$ & $\begin{array}{l}.087 \\
.081 \\
.101\end{array}$ & $\begin{array}{l}.077 \\
.069 \\
.070\end{array}$ & $\begin{array}{l}.079 \\
.071 \\
.078\end{array}$ & $\begin{array}{l}-52 \\
-57 \\
-49\end{array}$ & $\begin{array}{l}.164 \\
.166 \\
.152\end{array}$ \\
\hline $\begin{array}{l}357 \\
361 \\
373\end{array}$ & $\begin{array}{l}3 \\
5 \\
7\end{array}$ & $\begin{array}{l}20 \\
20 \\
20\end{array}$ & $\begin{array}{l}.176 \\
.171 \\
.160\end{array}$ & $\begin{array}{l}.168 \\
.166 \\
.149\end{array}$ & $\begin{array}{l}.170 \\
.167 \\
.152\end{array}$ & $\begin{array}{l}8 \\
0 \\
7\end{array}$ & $\begin{array}{l}.158 \\
.167 \\
.142\end{array}$ \\
\hline $\begin{array}{l}503 \\
519 \\
529\end{array}$ & $\begin{array}{l}3 \\
5 \\
7\end{array}$ & $\begin{array}{l}21 \\
21 \\
21\end{array}$ & $\begin{array}{l}.240 \\
.230 \\
.170\end{array}$ & $\begin{array}{l}.190 \\
.200 \\
.150\end{array}$ & $\begin{array}{l}.222 \\
.216 \\
.160\end{array}$ & $\begin{array}{r}29 \\
27 \\
-5\end{array}$ & $\begin{array}{l}.172 \\
.170 \\
.168\end{array}$ \\
\hline $\begin{array}{l}505 \\
515 \\
531\end{array}$ & $\begin{array}{l}3 \\
5 \\
7\end{array}$ & $\begin{array}{l}22 \\
22 \\
22\end{array}$ & $\begin{array}{l}.240 \\
.211 \\
.220\end{array}$ & $\begin{array}{l}.190 \\
.179 \\
.180\end{array}$ & $\begin{array}{l}.215 \\
.195 \\
.200\end{array}$ & $\begin{array}{r}26 \\
5 \\
15\end{array}$ & $\begin{array}{l}.171 \\
.185 \\
.164\end{array}$ \\
\hline $\begin{array}{l}507 \\
517 \\
527\end{array}$ & $\begin{array}{l}3 \\
5 \\
7\end{array}$ & $\begin{array}{l}23 \\
23 \\
23\end{array}$ & $\begin{array}{l}.124 \\
.130 \\
.160\end{array}$ & $\begin{array}{l}.105 \\
.106 \\
.100\end{array}$ & $\begin{array}{l}.118 \\
.125 \\
.130\end{array}$ & $\begin{array}{l}-28 \\
-28 \\
-24\end{array}$ & $\begin{array}{l}.164 \\
.174 \\
.172\end{array}$ \\
\hline $\begin{array}{l}509 \\
521 \\
533\end{array}$ & $\begin{array}{l}3 \\
5 \\
7\end{array}$ & $\begin{array}{l}24 \\
24 \\
24\end{array}$ & $\begin{array}{l}.220 \\
.180 \\
.230\end{array}$ & $\begin{array}{l}.200 \\
.170 \\
.220\end{array}$ & $\begin{array}{l}.215 \\
.177 \\
.225\end{array}$ & $\begin{array}{r}31 \\
-1 \\
36\end{array}$ & $\begin{array}{l}.164 \\
.178 \\
.166\end{array}$ \\
\hline $\begin{array}{l}511 \\
523 \\
535\end{array}$ & $\begin{array}{l}3 \\
5 \\
7\end{array}$ & $\begin{array}{l}25 \\
25 \\
25\end{array}$ & $\begin{array}{l}.170 \\
.190 \\
.190\end{array}$ & $\begin{array}{l}.166 \\
.176 \\
.180\end{array}$ & $\begin{array}{l}.168 \\
.179 \\
.181\end{array}$ & $\begin{array}{r}11 \\
1 \\
-1\end{array}$ & $\begin{array}{l}.152 \\
.178 \\
.182\end{array}$ \\
\hline $\begin{array}{l}575 \\
597 \\
603\end{array}$ & $\begin{array}{l}3 \\
5 \\
7\end{array}$ & $\begin{array}{l}26 \\
26 \\
26\end{array}$ & $\begin{array}{l}.090 \\
.130 \\
.100\end{array}$ & $\begin{array}{l}.060 \\
.070 \\
.040\end{array}$ & $\begin{array}{l}.068 \\
.090 \\
.058\end{array}$ & $\begin{array}{l}-56 \\
-45 \\
-62\end{array}$ & $\begin{array}{l}.155 \\
.165 \\
.154\end{array}$ \\
\hline $\begin{array}{l}577 \\
599 \\
605\end{array}$ & $\begin{array}{l}3 \\
5 \\
7\end{array}$ & $\begin{array}{l}27 \\
27 \\
27\end{array}$ & $\begin{array}{l}.053 \\
.060 \\
.040\end{array}$ & $\begin{array}{l}.038 \\
.036 \\
.030\end{array}$ & $\begin{array}{l}.047 \\
.052 \\
.037\end{array}$ & $\begin{array}{l}-70 \\
-68 \\
-77\end{array}$ & $\begin{array}{l}.159 \\
.163 \\
.158\end{array}$ \\
\hline $\begin{array}{l}579 \\
591 \\
607\end{array}$ & $\begin{array}{l}3 \\
5 \\
7\end{array}$ & $\begin{array}{l}28 \\
28 \\
28\end{array}$ & $\begin{array}{l}.070 \\
.094 \\
.100\end{array}$ & $\begin{array}{l}.070 \\
.086 \\
.070\end{array}$ & $\begin{array}{l}.070 \\
.090 \\
.090\end{array}$ & $\begin{array}{l}-56 \\
-46 \\
-40\end{array}$ & $\begin{array}{l}.159 \\
.167 \\
.149\end{array}$ \\
\hline $\begin{array}{l}581 \\
593 \\
609\end{array}$ & $\begin{array}{l}3 \\
5 \\
7\end{array}$ & $\begin{array}{l}29 \\
29 \\
29\end{array}$ & $\begin{array}{l}.060 \\
.049 \\
.052\end{array}$ & $\begin{array}{l}.048 \\
.030 \\
.050\end{array}$ & $\begin{array}{l}.057 \\
.045 \\
.052\end{array}$ & $\begin{array}{l}-64 \\
-73 \\
-64\end{array}$ & $\begin{array}{l}.158 \\
.165 \\
.143\end{array}$ \\
\hline $\begin{array}{l}583 \\
595 \\
611\end{array}$ & $\begin{array}{l}3 \\
5 \\
7\end{array}$ & $\begin{array}{l}30 \\
30 \\
30\end{array}$ & $\begin{array}{l}.260 \\
.230 \\
.160\end{array}$ & $\begin{array}{l}.220 \\
.200 \\
.150\end{array}$ & $\begin{array}{l}.230 \\
.212 \\
.159\end{array}$ & $\begin{array}{l}47 \\
30 \\
12\end{array}$ & $\begin{array}{l}.156 \\
.163 \\
.142\end{array}$ \\
\hline $\begin{array}{l}625 \\
634 \\
638\end{array}$ & $\begin{array}{l}3 \\
5 \\
7\end{array}$ & $\begin{array}{l}31 \\
31 \\
31\end{array}$ & $\begin{array}{l}.050 \\
.070 \\
.070\end{array}$ & $\begin{array}{l}.040 \\
.048 \\
.050\end{array}$ & $\begin{array}{l}.049 \\
.058 \\
.067\end{array}$ & $\begin{array}{l}-68 \\
-58 \\
-57\end{array}$ & $\begin{array}{l}.151 \\
.138 \\
.156\end{array}$ \\
\hline $\begin{array}{l}627 \\
631 \\
640\end{array}$ & $\begin{array}{l}3 \\
5 \\
7\end{array}$ & $\begin{array}{l}32 \\
32 \\
32\end{array}$ & $\begin{array}{l}.210 \\
.210 \\
.198\end{array}$ & $\begin{array}{l}.190 \\
.198 \\
.180\end{array}$ & $\begin{array}{l}.198 \\
.200 \\
.184\end{array}$ & $\begin{array}{l}32 \\
24 \\
16\end{array}$ & $\begin{array}{l}.150 \\
.161 \\
.158\end{array}$ \\
\hline
\end{tabular}

a Percentage increase in average $f$ relative to tests with 2110 oil.

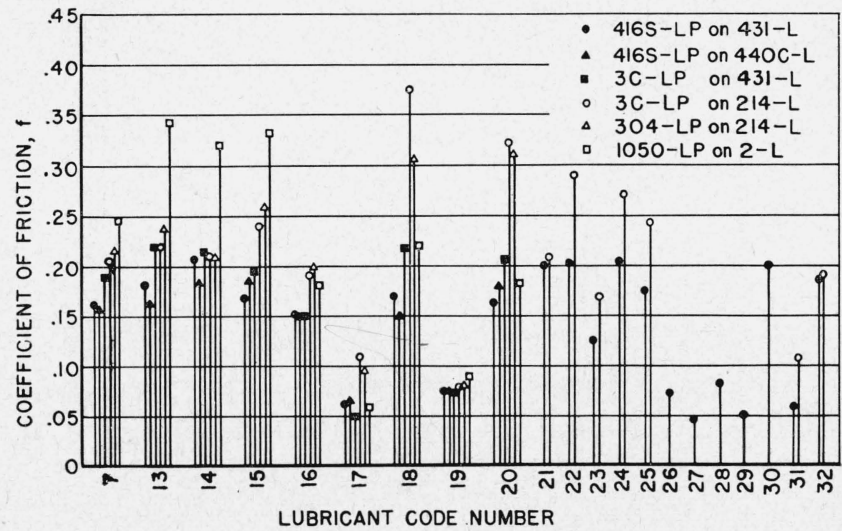

FIGURE 7. Summary of friction data for various lubricants with different metal combinations, at 10 -lb load and $100^{\circ} \mathrm{F}$.
Tables 2, 3, 4, 5, and 6 present similar data for the other metal combinations.

The data in the above tables are summarized in figure 7 . The average values of $f$ for lubricant 7 (2110 reference oil) and special lubricants 13 to 20 are given for six metal combinations. The averages for lubricants 21 to 25 and 31 and 32 are given for the two metal combinations used with them. Lubricants 26 to 30 were prepared at this Bureau and were tested with one metal combination only.

TABLE 2. Static friction data at $10-\mathrm{lb}$ load and $100^{\circ} \mathrm{F}$, for 416 stainless steel $(416 S-L P)$ on $440 C$ stainless steel $\left(440 C^{-}-L\right)$

\begin{tabular}{|c|c|c|c|c|c|c|c|}
\hline \multirow{2}{*}{$\begin{array}{l}\text { Test } \\
\text { No. }\end{array}$} & \multirow{2}{*}{$\begin{array}{l}\text { Position } \\
\text { No. }\end{array}$} & \multirow{2}{*}{$\begin{array}{c}\text { Lubri- } \\
\text { cant } \\
\text { Code } \\
\text { No. }\end{array}$} & \multicolumn{3}{|c|}{$f$ (tangent) } & \multirow{2}{*}{$\begin{array}{l}\text { Percent- } \\
\text { age in- } \\
\text { crease a }\end{array}$} & \multirow{2}{*}{$\begin{array}{c}f 2110 \\
\text { oil }\end{array}$} \\
\hline & & & $\begin{array}{l}\text { Maxi- } \\
\text { mum }\end{array}$ & $\begin{array}{l}\text { Mini- } \\
\text { mum }\end{array}$ & A verage & & \\
\hline $\begin{array}{l}86 \\
92\end{array}$ & $\frac{5}{7}$ & $\begin{array}{l}13 \\
13\end{array}$ & $\begin{array}{r}0.163 \\
.180\end{array}$ & $\begin{array}{r}0.158 \\
.159\end{array}$ & $\begin{array}{r}0.160 \\
.166\end{array}$ & $\begin{array}{r}7 \\
15\end{array}$ & $\begin{array}{l}0.150 \\
.144\end{array}$ \\
\hline 88 & 5 & 14 & .189 & .179 & .183 & 22 & .150 \\
\hline 94 & 7 & 14 & .188 & .182 & .185 & 23 & .150 \\
\hline 84 & 5 & 15 & .184 & .180 & .181 & 19 & .152 \\
\hline 96 & 7 & 15 & .195 & .184 & .188 & 24 & .152 \\
\hline 233 & 7 & 16 & .170 & .163 & .167 & -5 & .176 \\
\hline 241 & 5 & 16 & .174 & .160 & .165 & -7 & .178 \\
\hline 245 & 3 & 16 & .124 & .121 & .122 & -25 & .162 \\
\hline 235 & 7 & 17 & .097 & .091 & .095 & -49 & .175 \\
\hline 239 & 5 & 17 & .064 & .052 & .060 & -66 & .179 \\
\hline 247 & 3 & 17 & .044 & .029 & .039 & -76 & .160 \\
\hline 377 & 7 & 18 & .161 & .147 & .154 & 3 & .149 \\
\hline 390 & 5 & 18 & .169 & .130 & .138 & -1 & .139 \\
\hline 397 & 3 & 18 & .179 & .148 & .158 & 11 & .142 \\
\hline 379 & 7 & 19 & .085 & .070 & .074 & -50 & .148 \\
\hline 386 & 5 & 19 & .081 & .070 & .072 & -50 & .144 \\
\hline 399 & 3 & 19 & .096 & .070 & .081 & -43 & .143 \\
\hline 382 & 7 & & .190 & .170 & .184 & 15 & .160 \\
\hline 388 & 5 & 20 & .200 & .169 & .192 & 41 & .136 \\
\hline 395 & 3 & 20 & .170 & .158 & .162 & 17 & .139 \\
\hline
\end{tabular}

a Percentage increase in average $f$ relative to tests with 2110 oil.

TABLE 3. Static friction daia at 10 -lb load and $100^{\circ} \mathrm{F}$, for chromium plate $(3 C-L P)$ on 431 stainless steel (431-L)

\begin{tabular}{|c|c|c|c|c|c|c|c|}
\hline \multirow{2}{*}{$\begin{array}{l}\text { Test } \\
\text { No. }\end{array}$} & \multirow{2}{*}{$\begin{array}{c}\text { Position } \\
\text { No. }\end{array}$} & \multirow{2}{*}{$\begin{array}{c}\text { Lubri- } \\
\text { cant } \\
\text { Code } \\
\text { No. }\end{array}$} & \multicolumn{3}{|c|}{$f$ (tangent) } & \multirow{2}{*}{$\begin{array}{l}\text { Percent- } \\
\text { age in- } \\
\text { crease a }\end{array}$} & \multirow{2}{*}{$\begin{array}{c}f 2110 \\
\text { oil }\end{array}$} \\
\hline & & & $\begin{array}{l}\text { Maxi- } \\
\text { mum }\end{array}$ & $\begin{array}{l}\text { Mini- } \\
\text { mum }\end{array}$ & Average & & \\
\hline $\begin{array}{l}155 \\
165 \\
175\end{array}$ & $\begin{array}{l}3 \\
5 \\
7\end{array}$ & $\begin{array}{l}13 \\
13 \\
13\end{array}$ & $\begin{array}{r}0.278 \\
.210 \\
.210\end{array}$ & $\begin{array}{r}0.214 \\
.201 \\
.200\end{array}$ & $\begin{array}{r}0.252 \\
.205 \\
.202\end{array}$ & $\begin{array}{l}15 \\
40 \\
19\end{array}$ & $\begin{array}{r}0.219 \\
.146 \\
.170\end{array}$ \\
\hline $\begin{array}{l}157 \\
167 \\
171\end{array}$ & $\begin{array}{l}3 \\
5 \\
7\end{array}$ & $\begin{array}{l}14 \\
14 \\
14\end{array}$ & $\begin{array}{l}.242 \\
.217 \\
.211\end{array}$ & $\begin{array}{l}.221 \\
.207 \\
.196\end{array}$ & $\begin{array}{l}.237 \\
.211 \\
.199\end{array}$ & $\begin{array}{l}12 \\
37 \\
21\end{array}$ & $\begin{array}{l}.212 \\
.154 \\
.164\end{array}$ \\
\hline $\begin{array}{l}159 \\
163 \\
173\end{array}$ & $\begin{array}{l}3 \\
5 \\
7\end{array}$ & $\begin{array}{l}15 \\
15 \\
15\end{array}$ & $\begin{array}{l}.233 \\
.166 \\
.199\end{array}$ & $\begin{array}{l}.209 \\
.157 \\
.190\end{array}$ & $\begin{array}{l}.226 \\
.161 \\
.195\end{array}$ & $\begin{array}{l}24 \\
13 \\
14\end{array}$ & $\begin{array}{l}.182 \\
.143 \\
.171\end{array}$ \\
\hline $\begin{array}{l}269 \\
278 \\
283\end{array}$ & $\begin{array}{l}7 \\
5 \\
3\end{array}$ & $\begin{array}{l}16 \\
16 \\
16\end{array}$ & $\begin{array}{l}.172 \\
.171 \\
.139\end{array}$ & $\begin{array}{l}.168 \\
.110 \\
.121\end{array}$ & $\begin{array}{l}.170 \\
.150 \\
.130\end{array}$ & $\begin{array}{l}-19 \\
-13 \\
-37\end{array}$ & $\begin{array}{l}.210 \\
.175 \\
.207\end{array}$ \\
\hline $\begin{array}{l}271 \\
276 \\
285\end{array}$ & $\begin{array}{l}7 \\
5 \\
3\end{array}$ & $\begin{array}{l}17 \\
17 \\
17\end{array}$ & $\begin{array}{l}.058 \\
.061 \\
.050\end{array}$ & $\begin{array}{l}.050 \\
.039 \\
.032\end{array}$ & $\begin{array}{l}.053 \\
.056 \\
.044\end{array}$ & $\begin{array}{l}-74 \\
-68 \\
-78\end{array}$ & $\begin{array}{l}.205 \\
.173 \\
.204\end{array}$ \\
\hline $\begin{array}{l}429 \\
441 \\
448\end{array}$ & $\begin{array}{l}7 \\
5 \\
3\end{array}$ & $\begin{array}{l}18 \\
18 \\
18\end{array}$ & $\begin{array}{l}.239 \\
.270 \\
.196\end{array}$ & $\begin{array}{l}.198 \\
.238 \\
.174\end{array}$ & $\begin{array}{l}.213 \\
.253 \\
.184\end{array}$ & $\begin{array}{r}10 \\
17 \\
8\end{array}$ & $\begin{array}{l}.193 \\
.216 \\
.171\end{array}$ \\
\hline $\begin{array}{l}431 \\
437 \\
450\end{array}$ & $\begin{array}{l}7 \\
5 \\
3\end{array}$ & $\begin{array}{l}19 \\
19 \\
19\end{array}$ & $\begin{array}{l}.098 \\
.077 \\
.080\end{array}$ & $\begin{array}{l}.078 \\
.070 \\
.070\end{array}$ & $\begin{array}{l}.084 \\
.072 \\
.073\end{array}$ & $\begin{array}{l}-58 \\
-67 \\
-58\end{array}$ & $\begin{array}{l}.200 \\
.220 \\
.175\end{array}$ \\
\hline $\begin{array}{l}433 \\
439 \\
446\end{array}$ & $\begin{array}{l}7 \\
5 \\
3\end{array}$ & $\begin{array}{l}20 \\
20 \\
20\end{array}$ & $\begin{array}{l}.216 \\
.243 \\
.184\end{array}$ & $\begin{array}{l}.200 \\
.238 \\
.178\end{array}$ & $\begin{array}{l}.206 \\
.240 \\
.179\end{array}$ & $\begin{array}{r}6 \\
11 \\
-4\end{array}$ & $\begin{array}{l}.194 \\
.216 \\
.187\end{array}$ \\
\hline
\end{tabular}

a Percentage increase in average $f$ relative to tests with 2110 oil. 
TABLE 4. Static friction data at 10-lb load and $100^{\circ} \mathrm{F}$, for chromium plate $(3 C-L P)$ on 214 Alcoa alloy $(214-L)$

\begin{tabular}{|c|c|c|c|c|c|c|c|}
\hline \multirow{2}{*}{$\begin{array}{l}\text { Test } \\
\text { No. }\end{array}$} & \multirow{2}{*}{$\begin{array}{l}\text { Position } \\
\text { No. }\end{array}$} & \multirow{2}{*}{$\begin{array}{c}\text { Lubri- } \\
\text { cant } \\
\text { code } \\
\text { No. }\end{array}$} & \multicolumn{3}{|c|}{$f$ (tangent) } & \multirow{2}{*}{$\begin{array}{l}\text { Percent- } \\
\text { age in- } \\
\text { crease a }\end{array}$} & \multirow{2}{*}{$\begin{array}{c}f 2110 \\
\text { oil }\end{array}$} \\
\hline & & & $\begin{array}{l}\text { Maxi- } \\
\text { mum }\end{array}$ & $\begin{array}{l}\text { Mini- } \\
\text { mum }\end{array}$ & A verage & & \\
\hline $\begin{array}{l}179 \\
190 \\
200\end{array}$ & $\begin{array}{l}7 \\
5 \\
3\end{array}$ & $\begin{array}{l}13 \\
13 \\
13\end{array}$ & $\begin{array}{r}0.239 \\
.248 \\
.230\end{array}$ & $\begin{array}{r}0.182 \\
.187 \\
.199\end{array}$ & $\begin{array}{r}0.221 \\
.221 \\
.215\end{array}$ & $\begin{array}{r}12 \\
19 \\
7\end{array}$ & $\begin{array}{r}0.198 \\
.186 \\
.201\end{array}$ \\
\hline $\begin{array}{l}182 \\
192 \\
196\end{array}$ & $\begin{array}{l}7 \\
5 \\
3\end{array}$ & $\begin{array}{l}14 \\
14 \\
14\end{array}$ & $\begin{array}{l}.211 \\
.228 \\
.231\end{array}$ & $\begin{array}{l}.200 \\
.199 \\
.200\end{array}$ & $\begin{array}{l}.204 \\
.211 \\
.214\end{array}$ & $\begin{array}{r}9 \\
10 \\
3\end{array}$ & $\begin{array}{l}.188 \\
191 \\
.207\end{array}$ \\
\hline $\begin{array}{l}184 \\
188 \\
198\end{array}$ & $\begin{array}{l}7 \\
5 \\
3\end{array}$ & $\begin{array}{l}15 \\
15 \\
15\end{array}$ & $\begin{array}{l}.230 \\
.346 \\
.223\end{array}$ & $\begin{array}{l}.199 \\
.267 \\
.196\end{array}$ & $\begin{array}{l}.214 \\
.296 \\
.212\end{array}$ & $\begin{array}{r}14 \\
58 \\
3\end{array}$ & $\begin{array}{l}.188 \\
.187 \\
.206\end{array}$ \\
\hline $\begin{array}{l}289 \\
299 \\
303\end{array}$ & $\begin{array}{l}3 \\
5 \\
7\end{array}$ & $\begin{array}{l}16 \\
16 \\
16\end{array}$ & $\begin{array}{l}.211 \\
.200 \\
.200\end{array}$ & $\begin{array}{l}.172 \\
.180 \\
.180\end{array}$ & $\begin{array}{l}.192 \\
.185 \\
.192\end{array}$ & $\begin{array}{r}-4 \\
-15 \\
-10\end{array}$ & $\begin{array}{l}.200 \\
.218 \\
.214\end{array}$ \\
\hline $\begin{array}{l}326 \\
297 \\
305\end{array}$ & $\begin{array}{l}3 \\
5 \\
7\end{array}$ & $\begin{array}{l}17 \\
17 \\
17\end{array}$ & $\begin{array}{l}.068 \\
.200 \\
.137\end{array}$ & $\begin{array}{l}.048 \\
.174 \\
.049\end{array}$ & $\begin{array}{l}.062 \\
.195 \\
.077\end{array}$ & $\begin{array}{l}-71 \\
-12 \\
-63\end{array}$ & $\begin{array}{l}.214 \\
.245 \\
.210\end{array}$ \\
\hline $\begin{array}{l}454 \\
467 \\
473\end{array}$ & $\begin{array}{l}3 \\
5 \\
7\end{array}$ & $\begin{array}{l}18 \\
18 \\
18\end{array}$ & $\begin{array}{l}.367 \\
.460 \\
.470\end{array}$ & $\begin{array}{l}.253 \\
.340 \\
.360\end{array}$ & $\begin{array}{l}.292 \\
.406 \\
.425\end{array}$ & $\begin{array}{r}36 \\
79 \\
109\end{array}$ & $\begin{array}{l}.214 \\
.226 \\
.203\end{array}$ \\
\hline $\begin{array}{l}456 \\
463 \\
475\end{array}$ & $\begin{array}{l}3 \\
5 \\
7\end{array}$ & $\begin{array}{l}19 \\
19 \\
19\end{array}$ & $\begin{array}{l}.084 \\
.090 \\
.090\end{array}$ & $\begin{array}{l}.080 \\
.073 \\
.078\end{array}$ & $\begin{array}{l}.080 \\
.082 \\
.081\end{array}$ & $\begin{array}{l}-58 \\
-60 \\
-62\end{array}$ & $\begin{array}{l}.192 \\
.204 \\
.216\end{array}$ \\
\hline $\begin{array}{l}458 \\
465 \\
471\end{array}$ & $\begin{array}{l}3 \\
5 \\
7\end{array}$ & $\begin{array}{l}20 \\
20 \\
20\end{array}$ & $\begin{array}{l}.420 \\
.430 \\
.420\end{array}$ & $\begin{array}{l}.300 \\
.216 \\
.196\end{array}$ & $\begin{array}{l}.355 \\
.310 \\
.303\end{array}$ & $\begin{array}{l}70 \\
41 \\
52\end{array}$ & $\begin{array}{l}.209 \\
.220 \\
.200\end{array}$ \\
\hline $\begin{array}{l}539 \\
555 \\
565\end{array}$ & $\begin{array}{l}7 \\
5 \\
3\end{array}$ & $\begin{array}{l}21 \\
21 \\
21\end{array}$ & $\begin{array}{l}.260 \\
.220 \\
.190\end{array}$ & $\begin{array}{l}.220 \\
.190 \\
.170\end{array}$ & $\begin{array}{l}.242 \\
.200 \\
.180\end{array}$ & $\begin{array}{r}17 \\
2 \\
-16\end{array}$ & $\begin{array}{l}.206 \\
.197 \\
.214\end{array}$ \\
\hline $\begin{array}{l}541 \\
551 \\
567\end{array}$ & $\begin{array}{l}7 \\
5 \\
3\end{array}$ & $\begin{array}{l}22 \\
22 \\
22\end{array}$ & $\begin{array}{l}.330 \\
.290 \\
.270\end{array}$ & $\begin{array}{l}.320 \\
.270 \\
.260\end{array}$ & $\begin{array}{l}.323 \\
.279 \\
.265\end{array}$ & $\begin{array}{l}63 \\
28 \\
26\end{array}$ & $\begin{array}{l}.198 \\
.217 \\
.210\end{array}$ \\
\hline $\begin{array}{l}543 \\
553 \\
563\end{array}$ & $\begin{array}{l}7 \\
5 \\
3\end{array}$ & $\begin{array}{l}23 \\
23 \\
23\end{array}$ & $\begin{array}{l}180 \\
.180 \\
.190\end{array}$ & $\begin{array}{l}150 \\
.150 \\
.140\end{array}$ & $\begin{array}{l}169 \\
.169 \\
.165\end{array}$ & $\begin{array}{l}-11 \\
-21 \\
-25\end{array}$ & $\begin{array}{l}.190 \\
.213 \\
.221\end{array}$ \\
\hline $\begin{array}{l}545 \\
557 \\
569\end{array}$ & $\begin{array}{l}7 \\
5 \\
3\end{array}$ & $\begin{array}{l}24 \\
24 \\
24\end{array}$ & $\begin{array}{l}.280 \\
.300 \\
.270\end{array}$ & $\begin{array}{l}.230 \\
.260 \\
.250\end{array}$ & $\begin{array}{l}.261 \\
.284 \\
.265\end{array}$ & $\begin{array}{l}33 \\
46 \\
35\end{array}$ & $\begin{array}{l}.196 \\
.195 \\
.196\end{array}$ \\
\hline $\begin{array}{l}547 \\
559 \\
571\end{array}$ & $\begin{array}{l}7 \\
5 \\
3\end{array}$ & $\begin{array}{l}25 \\
25 \\
25\end{array}$ & $\begin{array}{l}.260 \\
.280 \\
.234\end{array}$ & $\begin{array}{l}.220 \\
.230 \\
.220\end{array}$ & $\begin{array}{l}.245 \\
.256 \\
.225\end{array}$ & $\begin{array}{l}32 \\
27 \\
18\end{array}$ & $\begin{array}{l}.185 \\
.202 \\
.190\end{array}$ \\
\hline $\begin{array}{l}645 \\
653 \\
657\end{array}$ & $\begin{array}{l}7 \\
5 \\
3\end{array}$ & $\begin{array}{l}31 \\
31 \\
31\end{array}$ & $\begin{array}{l}.140 \\
.120 \\
.140\end{array}$ & $\begin{array}{l}.040 \\
.070 \\
.070\end{array}$ & $\begin{array}{l}.111 \\
.099 \\
.114\end{array}$ & $\begin{array}{l}-49 \\
-52 \\
-37\end{array}$ & $\begin{array}{l}.219 \\
.206 \\
.181\end{array}$ \\
\hline $\begin{array}{l}647 \\
651 \\
659\end{array}$ & $\begin{array}{l}7 \\
5 \\
3\end{array}$ & $\begin{array}{l}32 \\
32 \\
32\end{array}$ & $\begin{array}{l}.212 \\
.230 \\
.180\end{array}$ & $\begin{array}{l}196 \\
.180 \\
.170\end{array}$ & $\begin{array}{l}.201 \\
.195 \\
.173\end{array}$ & $\begin{array}{r}0 \\
+4 \\
-14 \\
\end{array}$ & $\begin{array}{l}.201 \\
.204 \\
.201\end{array}$ \\
\hline
\end{tabular}

a Percentage increase in average $f$ relative to tests with 2110 oil.
TABLE 5. Static friction data at $10-\mathrm{lb}$ load and $100^{\circ} \mathrm{F}$, for 304 stainless steel $(304-L P)$ on 214 Alcoa alloy (214-L)

\begin{tabular}{|c|c|c|c|c|c|c|c|}
\hline \multirow{2}{*}{$\begin{array}{l}\text { Test } \\
\text { No. }\end{array}$} & \multirow{2}{*}{$\begin{array}{c}\text { Position } \\
\text { No. }\end{array}$} & \multirow{2}{*}{$\begin{array}{c}\text { Lubri- } \\
\text { cant } \\
\text { Code } \\
\text { No. }\end{array}$} & \multicolumn{3}{|c|}{$f$ (tangent) } & \multirow{2}{*}{$\begin{array}{l}\text { Percent- } \\
\text { age in- } \\
\text { crease a }\end{array}$} & \multirow{2}{*}{$\begin{array}{l}f 2110 \\
\text { Oil }\end{array}$} \\
\hline & & & $\begin{array}{l}\text { Maxi- } \\
\text { mum }\end{array}$ & $\begin{array}{l}\text { Mini- } \\
\text { mum }\end{array}$ & Average & & \\
\hline 108 & 7 & 13 & 0. 223 & 0.182 & 0. 214 & 1 & 0.212 \\
\hline 116 & 5 & 13 & .232 & .217 & .223 & 8 & .206 \\
\hline 148 & 3 & 13 & .293 & 237 & 277 & 14 & .239 \\
\hline 110 & 7 & 14 & .211 & .196 & .200 & -7 & .216 \\
\hline 118 & 5 & 14 & .222 & 201 & .208 & 0 & .207 \\
\hline 150 & 3 & 14 & .233 & .216 & .221 & -8 & .238 \\
\hline 112 & 7 & 15 & .219 & .181 & .208 & 2 & .203 \\
\hline 125 & 5 & 15 & .307 & .252 & .285 & 26 & .217 \\
\hline 146 & 3 & 15 & .316 & .272 & .289 & 27 & .227 \\
\hline 309 & 7 & 16 & .234 & .192 & .210 & -7 & .226 \\
\hline 317 & 5 & 16 & .180 & .176 & .179 & -19 & .220 \\
\hline 321 & 3 & 16 & .226 & .205 & .215 & -12 & .245 \\
\hline 311 & 7 & 17 & .180 & .120 & .168 & -21 & .214 \\
\hline 315 & 5 & 17 & .060 & .040 & 057 & -75 & .227 \\
\hline 323 & 3 & 17 & .070 & .045 & .060 & -75 & .240 \\
\hline 403 & 3 & 18 & .310 & .250 & .277 & 31 & .211 \\
\hline 414 & 5 & 18 & .360 & .250 & .309 & 47 & .210 \\
\hline 422 & 7 & 18 & .350 & .298 & .325 & 78 & .183 \\
\hline 405 & 3 & 19 & .082 & .070 & .072 & -64 & .201 \\
\hline 412 & 5 & 19 & .122 & .083 & .092 & -59 & .222 \\
\hline 424 & 7 & 19 & .085 & .073 & .078 & -58 & .185 \\
\hline 407 & 3 & 20 & .367 & .250 & .311 & 50 & .207 \\
\hline 416 & 5 & 20 & .380 & .319 & .359 & 64 & .219 \\
\hline 420 & 7 & 20 & .290 & .250 & .258 & 39 & .185 \\
\hline
\end{tabular}

a Percentage increase in average $f$ relative to tests with 2110 oil.

TABLE 6. Static friction data at 10-lb load and $100^{\circ} \mathrm{F}$, for 1050 steel $(1050-L P)$ on cast iron (2-L)

\begin{tabular}{|c|c|c|c|c|c|c|c|}
\hline \multirow{2}{*}{$\begin{array}{l}\text { Test } \\
\text { No. }\end{array}$} & \multirow{2}{*}{$\begin{array}{c}\text { Position } \\
\text { No. }\end{array}$} & \multirow{2}{*}{$\begin{array}{c}\text { Lubri- } \\
\text { cant } \\
\text { Code } \\
\text { No. }\end{array}$} & \multicolumn{3}{|c|}{$f$ (tangent) } & \multirow{2}{*}{$\begin{array}{l}\text { Percent- } \\
\text { age in- } \\
\text { crease a }\end{array}$} & \multirow{2}{*}{$\begin{array}{l}f \underset{ }{2110} \\
\text { Oil }\end{array}$} \\
\hline & & & $\begin{array}{l}\text { Maxi- } \\
\text { mum }\end{array}$ & $\begin{array}{l}\text { Mini- } \\
\text { mum }\end{array}$ & Average & & \\
\hline $\begin{array}{l}130 \\
138\end{array}$ & $\begin{array}{l}5 \\
7\end{array}$ & $\begin{array}{l}13 \\
13\end{array}$ & $\begin{array}{r}0.360 \\
.357\end{array}$ & $\begin{array}{r}0.326 \\
.317\end{array}$ & $\begin{array}{r}0.340 \\
.344\end{array}$ & $\begin{array}{l}19 \\
18\end{array}$ & $\begin{array}{r}0.286 \\
.292\end{array}$ \\
\hline $\begin{array}{l}132 \\
140\end{array}$ & $\begin{array}{l}5 \\
7\end{array}$ & $\begin{array}{l}14 \\
14\end{array}$ & $\begin{array}{l}.378 \\
.386\end{array}$ & $\begin{array}{l}.292 \\
.297\end{array}$ & $\begin{array}{l}.318 \\
.324\end{array}$ & $\begin{array}{r}10 \\
6\end{array}$ & $\begin{array}{l}.290 \\
.305\end{array}$ \\
\hline $\begin{array}{l}134 \\
142\end{array}$ & $\begin{array}{l}5 \\
7\end{array}$ & $\begin{array}{l}15 \\
15\end{array}$ & $\begin{array}{l}.367 \\
.318\end{array}$ & $\begin{array}{l}.329 \\
.308\end{array}$ & $\begin{array}{l}.353 \\
.312\end{array}$ & $\begin{array}{r}19 \\
4\end{array}$ & $\begin{array}{l}.298 \\
.302\end{array}$ \\
\hline $\begin{array}{l}251 \\
259 \\
263\end{array}$ & $\begin{array}{l}3 \\
5 \\
7\end{array}$ & $\begin{array}{l}16 \\
16 \\
16\end{array}$ & $\begin{array}{l}.173 \\
.192 \\
.210\end{array}$ & $\begin{array}{l}.148 \\
.171 \\
.192\end{array}$ & $\begin{array}{l}.160 \\
.177 \\
.198\end{array}$ & $\begin{array}{r}-23 \\
-43 \\
-13\end{array}$ & $\begin{array}{l}.207 \\
.308 \\
.227\end{array}$ \\
\hline $\begin{array}{l}253 \\
257 \\
265\end{array}$ & $\begin{array}{l}3 \\
5 \\
7\end{array}$ & $\begin{array}{l}17 \\
17 \\
17\end{array}$ & $\begin{array}{l}.078 \\
.088 \\
.082\end{array}$ & $\begin{array}{l}.060 \\
.038 \\
.045\end{array}$ & $\begin{array}{l}.070 \\
.057 \\
.057\end{array}$ & $\begin{array}{l}-67 \\
-81 \\
-76\end{array}$ & $\begin{array}{l}.213 \\
.299 \\
.237\end{array}$ \\
\hline $\begin{array}{l}479 \\
491 \\
497\end{array}$ & $\begin{array}{l}7 \\
5 \\
3\end{array}$ & $\begin{array}{l}18 \\
18 \\
18\end{array}$ & $\begin{array}{l}.240 \\
.220 \\
.270\end{array}$ & $\begin{array}{l}.220 \\
.168 \\
.240\end{array}$ & $\begin{array}{l}.222 \\
.189 \\
.249\end{array}$ & $\begin{array}{l}25 \\
10 \\
23\end{array}$ & $\begin{array}{l}.178 \\
.172 \\
.202\end{array}$ \\
\hline $\begin{array}{l}481 \\
487 \\
499\end{array}$ & $\begin{array}{l}7 \\
5 \\
5\end{array}$ & $\begin{array}{l}19 \\
19 \\
19\end{array}$ & $\begin{array}{l}.090 \\
.085 \\
.100\end{array}$ & $\begin{array}{l}.090 \\
.074 \\
.090\end{array}$ & $\begin{array}{l}.090 \\
.078 \\
.098\end{array}$ & $\begin{array}{l}-51 \\
-59 \\
-60\end{array}$ & $\begin{array}{l}.186 \\
.191 \\
.246\end{array}$ \\
\hline $\begin{array}{l}483 \\
489 \\
495\end{array}$ & $\begin{array}{l}7 \\
5 \\
3\end{array}$ & $\begin{array}{l}20 \\
20 \\
20\end{array}$ & $\begin{array}{l}.210 \\
.200 \\
.150\end{array}$ & $\begin{array}{l}.194 \\
.196 \\
.150\end{array}$ & $\begin{array}{l}.201 \\
.198 \\
.150\end{array}$ & $\begin{array}{r}14 \\
4 \\
-13\end{array}$ & $\begin{array}{l}.176 \\
.190 \\
.173\end{array}$ \\
\hline
\end{tabular}

a Percentage increase in average $f$ relative to tests with 2110 oil. 


\section{Conclusion}

For static friction under the conditions used for these tests, the following indications have been obtained:

1. Polished surfaces sliding on lapped surfaces tend to give lower friction and less variation than ground surfaces sliding on ground surfaces.

2. For the metal specimens tested, with most of the lubricants, the heat-treated stainless steel combinations gave the lowest friction. The chromiumplated rider on the heat-treated stainless steel plate also gave correspondingly low friction with lubricants 16,17 , and 19 . For the chromium-plated rider and the 304 stainless steel rider on the Alcoa 214 alloy plate, and for the 1050 steel rider on the cast iron plate, the relative friction varied greatly with the lubricant. Each of these combinations gave high friction with one or more lubricants while giving low friction with other lubricants.
3. The lubricants containing molybdenum disulfide gave the lowest friction, whereas mineral lubricating grease, dry molybdenum disulfide, and the lubricant containing graphite gave friction nearly as low. With the above lubricants the friction was about 50 to 60 percent less than with the 2110 reference oil. The lubricant containing an oxidized petroleum compound and the one containing a silicone grease gave slightly less friction than the 2110 oil. The chlorinated and fluorinated lubricants without additives and the remaining special lubricants gave higher friction than the 2110 reference oil.

These relative evaluations of friction apply only for static conditions as used in these tests. Any significance with respect to kinetic boundary lubrication is questionable, except possibly in those cases where the velocity approaches zero.

Washington, October 9, 1950. 